\title{
Connecting Genotypes and Phenotypes using Transformed Bacteria in a Wet Lab Setting
}

\author{
Brooke Trabona and Mindy Brooks
}

Louisiana State University, Department of Biological Sciences, 103 Life Sciences Bldg, Baton Rouge LA 70803 USA (btrabona@Isu.edu; mmccal5@Isu.edu)

\begin{abstract}
Taught as separate courses, a major difficulty in introductory biology courses is making the connection between Mendelian genetics and molecular biology. To help students better understand and integrate these concepts, Louisiana State University offer hands-on, inquiry-based lab exercises. Freshman biology students first plate Escherichia coli strains (A, B, and C) that were transformed by three different plasmids and expose them each to three treatments: the antibiotics tetracycline and ampicillin and ultra-violet light. At the second meeting, students perform gel electrophoresis with the three plasmids (1,2, and 3) used to transform the bacteria and analyze bacterial growth after 24 hours of incubation. By understanding the role of restriction enzymes and how to analyze plasmid maps, students are tasked with identifying plasmids 1,2 , and 3 by interpreting the gel fragment patterns. Students are then challenged to draw connections between the plasmid genotypes and the resulting bacterial phenotypes using a student guide to piece together which plasmids transformed the bacteria.
\end{abstract}

Keywords: transformed bacteria, plasmids, restriction enzymes, gel electrophoresis

\section{Mission, Review Process \& Disclaimer}

The Association for Biology Laboratory Education (ABLE) was founded in 1979 to promote information exchange among university and college educators actively concerned with teaching biology in a laboratory setting. The focus of ABLE is to improve the undergraduate biology laboratory experience by promoting the development and dissemination of interesting, innovative, and reliable laboratory exercises. For more information about ABLE, please visit http://www.ableweb.org/.

Advances in Biology Laboratory Education is the peer-reviewed publication of the conference of the Association for Biology Laboratory Education. Published articles and extended abstracts are evaluated and selected by a committee prior to presentation at the conference, peer-reviewed by participants at the conference, and edited by members of the ABLE Editorial Board. Published abstracts are evaluated and selected by a committee prior to presentation at the conference.

\section{Citing This Article}

Trabona B, Brooks M. 2020. Connecting genotypes and phenotypes using transformed bacteria in a wet lab setting. Article 86 In: McMahon K, editor Advances in biology laboratory education. Volume 41. Publication of the 41st Conference of the Association for Biology Laboratory Education (ABLE). https://doi.org/10.37590/able.v41.abs86

Compilation (C) 2020 by the Association for Biology Laboratory Education, ISBN 1-890444-17-0. All rights reserved. No part of this publication may be reproduced, stored in a retrieval system, or transmitted, in any form or by any means, electronic, mechanical, photocopying, recording, or otherwise, without the prior written permission of the copyright owner.

ABLE strongly encourages individuals to use the exercises in this volume in their teaching program. If this exercise is used solely at one's own institution with no intent for profit, it is excluded from the preceding copyright restriction, unless otherwise noted on the copyright notice of the individual chapter in this volume. Proper credit to this publication must be included in your laboratory outline for each use; a sample citation is given above. 